\title{
Japanese ministry requests large increase for competitive university grants
}

Tokyo. Japan's Ministry of Education, Science and Culture (MESC) has requested the largest increase in 15 years for its competitive research grants for university researchers. The proposed 16 per cent increase to $¥ 75$ billion (US $\$ 600$ million) for the fiscal year that starts on 1 April 1993 follows a similarly large increase requested by the Ministry of International Trade and Industry (MITI) (see Nature 359, 4; 1992) and reflects a commitment by Japan's sciencerelated ministries and agencies to achieving the government's goal of doubling its spending on research in the next few years.

The request comes a few weeks after the science council of MESC recommended that the competitive grants budget be increased by 50 per cent to $¥ 100$ billion "at an early stage" (see Nature 358, $359 ; 1992)$. The request must be approved by the Ministry of Finance and the Diet, but its budgets generally undergo only minor trimming. Last year, for example, a request for 10.5 per cent more for competitive grants wound up as an increase of 9.7 per cent.

A rapidly rising competitive grants budget conforms to a standing policy by the ministry's bureaucrats to put a larger portion of the research grants budget on a competitive basis. Although the competitive grant budget has increased by

5-10 per cent a year in recent years, well above inflation, the budget for fixed maintenance grants of a few million yen $(\$ 10,000-\$ 20,000)$ a year to all science and engineering professors has decreased in real terms almost every year since 1970

Highlights of budget proposal for MESC

Grants-in-aid of research

Government/industry research

Donations from industry

Nuclear fusion

Accelerator physics (TRISTAN)

Space science

$\frac{\text { billion } ¥}{75.0}$

15.3

50.1

12.8

13.0

20.8

4.0

Earthquake \& volcanic eruption prediction 2.4

Antarctic research

3.7

9.6

world's largest helical fusion device, under construction at the new national fusion research institute in Gifu Prefecture, would rise by more than 20 per cent, to $¥ 12.8$ billion. The ministry has also asked for 25 per cent more for the Japan Society for the Promotion of Science, which provides postdoctoral fellowships for Japanese and foreign researchers.

$\%$ from 1992

$+16.1$

$+3.2$

$+4.1$

$+20.4$

$-9.0$

$-0.5$

$+38.9$

$+5.5$

$+5.7$

$+24.8$

One programme being trimmed, by 9 per cent, is the TRISTAN electron-positron collider in the high-energy physics laboratory at Tsukuba science city, as attention shifts to the more powerful Large Electron-Positron (LEP) collider in Europe. The earthquake and volcanic eruption prediction programmes would receive a 5.5 per cent increase despite doubts about whether earthquake prediction is within the present capabilities of science (see

(see Nature 339; 576; 1989).

But more money and greater competition are not the only changes needed in the grants system. Young university researchers say the process of reviewing competitive grant applications must be made more open; at present, small committees of senior academics review applications in secret and do not explain their actions.

MESC has also requested a large increase for an 8-metre infrared telescope being built in Hawaii. And spending on the
Nature 358; 361; 1992). The ministry's Antarctic research base gets a similar increase.

The large increases requested by MESC and MITI go some way towards reaching a goal approved by the cabinet earlier this year of doubling Japan's government research budget in the near future. But maintaining the present growth rates will require Japanese industry and the public to accept some form of extra taxes.

David Swinbanks

\section{SKB announces UK redundancies and realignment}

\begin{abstract}
Munich and London. SmithKline Beecham has dismissed 150 British employees as part of a realignment of its research and development efforts. Although the redundancies within the 5,000-person work force were larger than expected, last week's announcement ends the uncertainties about the drug company's British operations since the merger between US-based SmithKline Beckman and UK-based Beecham in July 1989.
\end{abstract}

The company's eight research sites scattered across Britain will be combined into six as quickly as possible. The 2,000 researchers in the United States are not affected.

The long-expected reorganization leaves researchers in Britain focused mainly on the central nervous system, although the highly successful antiinfection programme built up by Beecham will be maintained. All cardiopulmonary work, some of which was carried out in Britain, will now be done in the United States, and vaccine work will continue in Belgium.

But much of the company's work on peripheral systems, notably gastrointestinal, has been swept away by the changes. Twenty years ago, this area provided the mainstay of SmithKline's profits after Nobel prizewinner James Black developed for them a new class of drugs the antiulcer $\mathrm{H}_{2}$ receptor antagonists, the world's second most commonly prescribed drugs. Cimetidine, marketed by SmithKline as Tagamet, has had annual sales of more than US\$1 billion in the last six years.

But patent rights are running out, and a new class of more potent antiulcer drug proton-pump inhibitors such as Astra's omeprazole - is now on the market. SmithKline Beecham has decided not to continue its search for new therapeutic targets in this area.

The changes also mean an internal restructuring away from a project-orientated approach to research towards a departmental system. For example, groups previously assigned to a specific illness such as depression will become part of a large neuroscience department. SmithKline Beecham says that teams will be integrated into the new structure without senior scientists losing their status.

SmithKline Beecham is the fifthhighest corporate spender on research in Britain. Within the pharmaceutical industry, the $£ 432$ million it invested last year ranked second only to the $£ 475$ million spent by Glaxo.

Alison Abbott \& lan Mundell 